Volume 1 Nomor 1, Maret 2019, Halaman 1 - 16

\title{
PENYULUHAN PROSPEK BETERNAK KAMBING DAN DOMBA BAGI MAYARAKAT TERDAMPAK PROYEK PLN SUMUR ADEM II KABUPATEN INDRAMAYU
}

\author{
Yudhi Mahmud \\ Universitas Wiralodra, yudhi8527@gmail.com
}

\begin{abstract}
Abstrak
Kegiatan pengabdian pada masyarakat berupa penyuluhan ini bertujuan untuk memberikan tambahan pengetahuan dan ketrampilan dalam berusaha dan beternak kambing yang baik. Khalayak sasaran dalam kegiatan $\mathrm{PkM}$ ini adalah petani dan buruh tani. Kegiatan ini bertujuan untuk memberikan pengetahuan dan keterampilan dalam Rangka mempersiapkan warga masyarakat yang terdampak pembangunan proyek memiliki usaha untuk mata pencahariannya sebagai pengganti kegiatan usaha tani hilang karena lahannya digunakan untuk pembangunan pembangkit tenaga uap Sumur Adem II. Manfaat yang diharapkan dari kegiatan pengabdian kepada masyarakat ini adalah sebagai forum untuk bertukar pikiran antara warga masyarakat dengan perguruan tinggi dan memberikan pengetahuan dan keterampilan kepada warga masyarakat dalam beternak kambing dan domba yang baik.

Kata kunci: Berternak kambing dan domba, pengetahuan, ketrampilan, beternak.

Abstract

Community service activities in the form of counseling aim to provide additional knowledge and skills in doing good business and raising goats. The target audience in this PKM activity is farmers and farm laborers. This activity aims to provide knowledge and skills in order to prepare the people affected by the project development to have a business for their livelihood as a substitute for lost farming activities because the land is used for the construction of the Sumur Adem II steam power plant. The expected benefits of community service activities are as a forum for exchanging ideas between citizens and universities and providing knowledge and skills to residents in raising good goats and sheep.
\end{abstract}

Keywords: Breeding goats and sheep, knowledge, skills, raising.

\section{PENDAHULUAN}

Kegiatan pengabdian pada masyarakat berupa penyuluhan ini bertujuan untuk memberikan tambahan pengetahuan dan ketrampilan dalam berusaha dan beternak kambing yang baik. Penambahan pengetahuan melalui penyuluhan ini diharapkan dapat mempercepat pemahaman masyarakat dalam beternak kambing dan domba yang baik. Metode ceramah digunakan untuk menjelaskan prospek usaha beternak, 
pemilihan bibit ternak dan pemeliharaan ternak kambing. Metode demonstrasi dipakai untuk menunjukkan bagaimana menyusun ransum yang baik dan mengolah hijauan makan ternak. Sementara metode tanya jawab untuk memberi kesempatan para peserta berkonsultasi dalam mengatasi kendala dalam beternak kambing dan domba.

Khalayak sasaran dalam kegiatan PkM ini adalah petani dan buruh tani warga masyarakat Desa Patrol Baru dan Desa Mekarsari Kecamatan Patrol yang terdampak proyek pembangunan PLTU PLN Sumur Adem II. Penyuluhan dilakukan dengan metode ceramah, demonstrasi dan latihan yang disertai tanya jawab. Metode ceramah digunakan untuk menjelaskan prospek usaha beternak, pemilihan bibit ternak dan pemeliharaan ternak kambing. Metode demonstrasi dipakai untuk menunjukkan bagaimana menyusun ransum yang baik dan mengolah hijauan makan ternak. Sementara metode tanya jawab untuk memberi kesempatan para peserta berkonsultasi dalam mengatasi kendala dalam beternak kambing dan domba.

Kesejahteraan petani merupakan tujuan utama untuk pembangunan pertanian, sektor pertanian dan peternakan sangat besar kontribusinya, terutama dalam peningkatan perekonomian masyarakat. Usaha ternak kambing merupakan komponen yang sangat penting dalam usahatani ternak di pedesaan, karena pemeliharaan ternak kambing dengan skala kecil dapat membantu perekonomian peternak. Disamping itu kambing juga merupakan salah satu satu komoditas yang banyak dipelihara oleh peternak kecil, dan sebagai fungsi pendapatan utama, tabungan untuk kebutuhan anak sekolah dan lainnya. Hal ini sesuai dengan pendapat Sumoprastowo (1980) bah2wa beberapa sifat yang menguntungkan dari usaha kambing yaitu kambing berkembang biak cukup pesat, modal usaha relatif kecil, pemeliharaannya sederhana, dapat memanfaatkan lahan kosong dan dapat berfungsi sebagai tabungan keluarga.

Ternak kambing mampu berkembang dan bertahan di semua zona agroekologi dan hampir tidak terpisahkan dari sistim usaha tani (Devendra and McLeroy, 1982; Wilson, 1995). Di banyak negara berkembang, ternak kambing telah dijadikan sebagai komuditas strategis sebagai instrumen pengentasan 
kemiskinan (poverty alleviation) oleh kelembagaan internasional. Peran ternak tersebut sangat strategis bagi kehidupan masyarakat pedesaan dan berkembang di hampir seluruh wilayah Indonesia. Ternak kambing memainkan peran yang penting sebagai sumber pendapatan dan mengurangi kemiskinan (FAO, 1999; Devendra 2000; Sodiq, 2005) disamping itu berperan sebagai pemacu program peningkatan konsumsi protein hewani.

Peluang usaha ternak kambing merupakan salah satu peluang usaha yang menguntungkan dan menjanjikan untung besar adalah usaha peternakan. Bisnis perternakan sangat cocok dijalankan di Indonesia khususnya di daerah pedesaan karena banyak rumput dan dedaunan yang dapat digunakan untuk pakan ternak dan pemeliharaan ternak kambing sebenarnya terbilang sangat mudah, karena tidak membutuhkan keterampilan yang khusus, sehingga peternak baru pun mampu secara cepat belajar manajemen pemeliharaan. Selain itu, dalam usaha ternak kambing tidak perlu memiliki lahan yang luas, hanya diperlukan kandang (sesuai dengan jumlah yang akan dipelihara), pakan yang dapat diambil dari kebun atau lingkungan sekitar, lapangan umum atau digembalakan di lahan-lahan umum. Ternak kambing merupakan salah satu sumber bahan pangan akan selalu meningkat permintaannya seiring dengan peningkatan jumlah pendudukan dan pendapatan masyarakat. Selain itu ternak kambing selain sebagai bahan pangan dapat digunakan untuk keperluan ibadah Agama Islam seperti untuk keperluan Aqiqah dan Qurban sehingga peluang pasar untuk ternak kambing ini sangat besar.

Salah satu keberhasilan para peternak adalah mendapatkan ternaknya yang sehat dan berkualitas baik yang dapat meningkatkan harga jual, sehingga dapat meningkatkan pendapatan petani. Populasi kambing dan domba sekitar 14,8 dan 7,6 juta ekor (Dirjen PKH, 2015) yang tersebar diseluruh Indonesia dan hampir seluruhnya dipelihara di pedesaan. Petani Peternak umumnya memelihara ternak sebagai tabungan dengan pola pemeliharaan masih tradisional dengan rataan jumlah kepemilikan ternak berkisar antara 3-5 ekor/petani (Dirjen PKH, 2015) Sumbangan ternak kambing dan domba terhadap pengadaan daging nasional cukup memberikan kontribusi yang berarti, terutama untuk kalangan masyarakat menegah ke bawah. Untuk meningkatkan produktivitas ternak, perlu dilakukan penyuluhan-penyuluhan 
mengenai tatalaksana pemeliharaan dan perawatan ternak yang baik seperti cara penyiapan dan pembuatan kandang yang sehat, cara pemilihan bibit yang baik, dan cara pemeliharaan serta perawatan ternak.

Pemilihan lokasi Untuk menempatkan kandang, tempat yang dipilih adalah: (1) Tempat yang agak tinggi dan tidak tergenang air; (2)Agak jauh dari rumah atau sumur; (3) Cukup mendapatkan sinar matahari pagi; dan (4) Terlindung dari tiupan angin langsung (terutama pada malam hari). Fungsi utama Kandang adalah antara lain: sebagai tempat istirahat; untuk melindungi dari pemangsa terutama anjing; untuk tempat makan dan minum apabila tidak digembalakan; sebagai tempat untuk kawin dan beranak; tempat kotoran dan kencing ternak; dan untuk mempermudah dalam pengontrolan ternak. Pemilihan bahan untuk kandang dan ukuran kandang Bahan kandang dipilih yang mudah didapat, murah, kuat dan tahan lama. Untuk bahan atap kandang, sebaiknya dipilih yang tidak menimbulkan panas seperti atap dari genting, ijuk atau rumbia.

Ukuran kandang harus disesuaikan dengan kebutuhan, dengan pemisahan antara kandang induk dengan pejantan. Untuk dewasa ukuran kandang adalah 1-1,5 meter persegi. Untuk kesehatan ternak, kandang harus dibersihkan secara rutin seperti membersihkan lantai kandang dan kokopan tempat pakan. Jika terdapat bagian yang rusak, segera diperbaiki. Pemilihan bibit yang baik untuk mencapai keberhasilan dalam usaha ternak kambing sangat penting. Bibit ternak yang baik dijamin akan mendapatkan produktivitas yang baik, sehingga akan memberikan keuntungan pada petani . Oleh karena itu, maka carilah dari bangsa (ras) dari bibit kambing unggul . Tanda-tanda calon Induk yang baik adalah: 1) Ternak kelihatan sehat, tidak cacat dan tidak terlalu gemuk. 2) Kaki lurus dan kuat. 3) Alat kelamin normal. 4) Harus mempunyai sifat keibuan (mau mengasuh anaknya) dengan baik Kambing normal. 5) Berasal dari keturunan kembar. 6) Bulu bersih dan mengkilap. 7) Minimal umur 5-6 bulan . Tanda-tandan bibit pejantan yang baik adalah: 1) Tubuh besar, badan relative panjang. 2) Tidak cacat. 3) Dada dalam dan lebar. 4) Kaki kuat dan lurus serta memiliki tumit tinggi. 5) Buah zakar normal (2 bush) sama besar dan kenyal. 6) Alat kelamin kenyal dan dapat ereksi. 7) Berasal dari keturunan kembar. 8) Bulu bersih clan mengkilap. 9) Minimal telah berumur 5-8 bulan. 
Pemeliharaan dan perawatan kesehatan cara mengerjakannya satu sama lain saling terkait dan saling berhubungan maka dalam hal ini tidak bisa terpisahkan. Pemeliharaan Pemeliharaan ternak kambing. Faktor-faktor pemeliharaan diantaranya meliputi, memandikan ternak, mencukur bulu, pemotongan kuku, dan pemberian pakan.

Pakan adalah suatu bahan yang dikonsumsi ternak yang didalamnya mengandung energi dan zat-zat gizi (atau keduanya). Pakan adalah bahan yang dimakan dan dicerna oleh seekor hewan yang mampu menyajikan unsur hara atau nutrien yang penting untuk perawatan tubuh, pertumbuhan, penggemukan, reproduksi dan produksi (Hartadi et al.,1986). Menurut Setiawan dan Arsa (2005), secara umum pakan ternak kambing sebenarnya hanya terdiri dari tiga jenis, yaitu pakan kasar, pakan penguat dan pakan pengganti. Pakan kasar merupakan bahan pakan berkadar serat kasar tinggi. Bahan ini berupa pakan hijauan yang terdiri dari rumput dan dedaunan.

Pakan penguat merupakan bahan pakan berkadar serat rendah dan mudah dicerna seperti konsentrat, ampas tahu dan bubur singkong. Sementara pakan pengganti merupakan pakan hijauan yang sudah difermentasi. Kambing sangat efisien dalam mengubah pakan berkualitas rendah menjadi protein yang berkualitas tinggi (Blakely dan Bade , 1994).

Rumput merupakan makanan pokok yang harus tersedia setiap hari, yang digunakan untuk memenuhi kebutuhan hidup seperti untuk metabolisma, untuk kebutuhan produksi susu dan untuk kebutuhan bereproduksi (kawin, bunting, beranak dan menyusui). Untuk ternak-ternak yang selalu dikandangkan, pemberiannya rumput adalah sebanyak $10 \%$ dan konsentrat $1 \%$ dari bobot badan hidup. Selain jenis rumput-rumputan, diberikan juga jenis hijauan lain seperti daun singkong, dan daun glyrisidia yang pemberiannya setelah proses pelayuan. Pemberian dalam bentuk segar, sebaiknya dihindari kaarena tanaman ini mengandung racun. Dengan pelayuan, maka semua racun yang ada dapat berkurang. Pemberian yang bebas akan memberikan pertumbuhan yang lebih cepat pada ternak, karena hijauan tersebut bernilai gizi tinggi. Ada satu jenis hijuan makanan ternak yang memiliki kandungan protein tinggi dan memiliki anti nutrient 
rendah yaitu indigofera $s p$, cara pemberian dapat langsung dalam bentuk segar maupun diolah terlebih dahulu menjadi tepung.

Pakan kambing sebagian besar terdiri dari hijauan, yaitu rumput dan daun daunan tertentu (daun nangka, daun waru, daun pisang dan daunan leguminosa). Seekor kambing dewasa membutuhkan kira-kira $6 \mathrm{~kg}$ hijauan segar sehari yang diberikan 2 kali, yaitu pagi dan sore. Tetapi kambing lebih suka mencari dan memilih pakannya sendiri di alam terbuka (Sosroamidjojo, 1991). Siregar (1995) menjelaskan bahwa pemberian hijauan terbagi menjadi 2 macam yaitu hijauan yang diberikan dalam keadaan masih segar dengan kadar air $70 \%$ dan hijauan yang diberikan dalam keadaan kering atau awetan. Hijauan kering dapat berupa hay, sedangkan awetan dapat berupa silase.

Pemberian pakan hijauan diberikan sesuai kebutuhan ternak yaitu $3-4 \%$ bahan kering dari bobot hidup. Hijauan merupakan bahan pakan berserat kasar yang dapat berasal dari rumput dan dedaunan. Kebutuhan hijauan untuk kambing sekitar $70 \%$ dari total pakan (Setiawan dan Arsa, 2005). Pada dasarnya kambing tidak selektif dalam memilih pakan. Segala macam daun-daunan dan rumput disukai, tetapi hijauan dari daun-daunan lebih disukai daripada rumput. Hijauan yang baik untuk pakan adalah hijauan yang belum terlalu tua dan belum menghasilkan bunga karena hijauan yang masih muda memiliki kandungan PK (protein kasar) yang lebih tinggi. Hijauan yang diperoleh pada musim hujan sebaiknya dilayukan atau dikeringkan terlebih dahulu sebelum digunakan untuk pakan kambing, (Murtidjo, 1993).

Hijauan pakan merupakan pakan utama bagi ternak ruminansia dan berfungsi sebagai sumber gizi, yaitu protein, sumber tenaga, vitamin dan mineral. Kambing akan memperoleh semua gizi yang dibutuhkan dari hijauan bila pakan berupa campuran daun-daunan dan rumput-rumputan dicampur dengan perbandingan $1: 1$. Dengan komposisi demikian, zat gizi yang terdapat pada masing-masing jenis hijauan yang diberikan tersebut akan saling melengkapi dan menjamin ketersediaan gizi yang lebih baik sehingga pencernaan tidak terganggu (Mulyono dan Sarwono, 2008). Konsentrat serta bahan berserat merupakan komponen atau penyusun ransum (Blakely dan Bade, 1994). Konsentrat adalah 
bahan pakan yang digunakan bersama bahan pakan lain untuk meningkatkan keserasian gizi dari keseluruhan pakan dan dimaksudkan untuk disatukan atau dicampur sebagai suplemen atau bahan pelengkap (Hartadi et al., 1980). Murtidjo (1993) menjelaskan bahwa konsentrat untuk ternak kambing umumnya disebut sebagai pakan penguat atau bahan baku pakan yang memiliki kandungan serat kasar kurang dari $18 \%$ dan mudah dicerna. Pakan penguat dapat berupa dedak jagung, ampas tahu, bungkil kelapa, bungkil kacang tanah, atau campuran pakan tersebut. Untuk kambing jantan yang sedang dalam periode memacek sebaiknya ditambah pakan penguat (konsentrat) $\pm 1 \mathrm{~kg}$. Konsentrat yang terdiri dari campuran 1 bagian dedak dengan 1 bagian bungkil kelapa ditambah garam secukupnya adalah cukup baik sebagai pakan penguat. Pakan penguat tersebut diberikan sehari sekali dalam bentuk bubur yang kental (Sosroamidjojo, 1985).

Pemanfaatan hijauan pakan sebagai makanan ternak kambing harus disuplementasikan dengan makanan penguat atau konsentrat agar kebutuhan nutrisi terhadap pakan dapat terpenuhi. Tujuan suplementasi makanan penguat dalam makanan ternak kambing adalah untuk meningkatkan daya guna makanan atau menambah nilai gizi makanan, menambah unsur makanan yang defisien serta meningkatkan konsumsi dan kecernaan makanan. Keuntungan yang diperoleh dari pemberian pakan kasar bersama makanan penguat adalah adanya kecenderungan mikroorganisme dalam rumen dapat memanfaatkan makanan penguat terlebih dahulu sebagai sumber energi dan selanjutnya memanfaatkan makanan kasar yang ada. Dengan demikian mikroorganisme rumen lebih mudah dan lebih cepat berkembang populasinya, sehingga akan semakin banyak makanan yang harus dikonsumsi ternak kambing (Murtidjo, 1993). Pembuatan pakan konsentrat diformulasi sebagai berikut: bekatul $35 \%$, pollard 20\%, bungkil kedelai $13 \%$, empok jagung 8\%, onggok 20\%, mineral dan garam dapur 4\% (Ali, dkk, 2012). Menurut Siregar (1994) standar nutrien dalam konsentrat untuk penggemukan kambing, protein minimal $16 \%$ dan serat kasar kurang $18 \%$. Strategi pemberian konsentrat dengan dicomborkan sebelumnya pakan konsentrat dimasukkan sejumlah air panas membentuk comboran cair, diaduk merata, menunggu dingin baru diberikan pada ternak. Dengan demikian akan meningkatkan efisiensi pakan 
karena nutrien konsentrat menjadi bypass. Untuk kambing sedang tumbuh, kebutuhan protein kasar ransum sebesar 14-19\%, DE =3,0 Mcal dan kebutuhan bahan kering hampir sama yaitu 3,5\% dari bobot hidup (NRC, 1981). Namun menurut Haryanto dan Djajanegara (1993) kambing sedang tumbuh khususnya di Indonesia, kebutuhan protein ransum $12-14 \%$ dan $\mathrm{DE}=2,8 \mathrm{Mcal}$.

Adapun ketersediaan air minum untuk kambing harus ada setiap saat (Sutama dan Budiarsana, 2009). Meskipun sebagian besar air didapat dari hijauan rumput atau daun-daunan, kambing tetap harus diberi minum. Air diperlukan untuk membantu proses pencernaan, mengeluarkan bahan-bahan yang tidak berguna dari dalam tubuh (keringat, air kencing dan kotoran), melumasi persendian dan membuat tubuh tidak kepanasan. Volume kebutuhan air pada kambing sangat bervariasi, dipengaruhi oleh jenis kambing, suhu lingkungan, jenis pakan yang diberikan, dan kegiatan kambing. Bila bobot kambing hidup $40 \mathrm{~kg} / \mathrm{ekor}$ dan ransum kering (dalam bahan kering) yang dibutuhkan ternak rata-rata sebanyak $0,8 \mathrm{~kg}$ dan air minum minimal sebanyak 3 x 1 liter (3 liter). Kebutuhan air minum untuk kambing berkisar 3-5 liter sehari (Mulyono dan Sarwono, 2008).

Manajemen pemberian pakan yang baik perlu dipelajari karena merupakan upaya untuk memperbaiki kualitas pakan yang diberikan. Pemberian pakan yang tidak memenuhi kebutuhan ternak akan merugikan. Manajemen pemberian pakan harus memperhatikan penyusunan ransum kebutuhan zat-zat untuk ternak yang meliputi jenis ternak, berat badan, tingkat pertumbuhan, tingkat produksi, dan jenis produksi (Chuzaemi dan Hartutik, 1988).

Pakan yang diberikan kepada ternak potong sebaiknya pakan yang masih segar. Bila pakan berada di dalam palungan lebih dari 12 jam maka pakan tersebut akan menjadi basi, apek dan mudah berjamur. Pakan yang sudah basi akan menyebabkan pengambilan (intake) pakan oleh ternak berkurang dan hal ini akan berdampak terhadap menurunnya performa ternak. Setiap terjadi penurunan 1,0\% akan menyebabkan menurunnya pertambahan bobot badan sebesar 1,5-2,0 \% . Untuk menjamin pakan di dalam palungan selalu segar, lakukan pemberian pakan minimal 2 kali sehari, bila terdapat sisa pakan dari pemberian sebelumnya harus dibuang. Idealnya ternak harus sudah diberikan pakan kembali kira -kira setengah 
jam setelah pakan pada pemberian sebelumnya habis. Inilah pentingnya menyusun ransum yang sesuai dengan kebutuhan ternak (Santosa, 2006).

Bahan pakan penggemukan dapat beragam, tetapi komposisi gizi harus sesuai untuk tujuan produksi (penggemukan). Jumlah pemberian tergantung berat badan $(10-15 \%)$. Perbandingan pakan hijauan dan pakan tambahan (konsentrat) minimal $80: 20$. Adapun jenis pakan tambahan lainnya dapat berupa campuran beberapa limbah hasil pertanian, seperti ampas kacang kedelai, dedak padi, dedak gandum, bungkil inti sawi, bungkil kelapa, serta molases dan mineral atau vitamin. Pakan tambahan tersebut diberikan sebanyak 0,5 - 1 kg/ekor/hari dengan PK 14 $16 \%$. (Sutama dan Budiarsana, 2009).

Menurut Pamungkas, dkk, (2005) upaya dapat dilakukan untuk meningkatkan laju pertumbuhan kambing peranakan boer dengan menyediakan asupan nutrisi yang cukup, salah satunya dengan memberikan pakan lengkap (complete Feed atau Total Mix Ration). Pakan lengkap yang dimaksud adalah campuran antara hijauan atau sumber serat dengan konsentrat dalam bentuk yang homogen (uniform) dengan kandungan nutrisi sesuai dengan kebutuhan ternak, dengan demikian begitu ternak mengkonsumsi pakan ini sekaligus hijauan dan konsentrat masuk bersama-sama dalam rumen. Pemberian pakan dengan pakan lengkap ini lebih sederhana karena peternak hanya menentukan jumlahnya serta menyediakan air minum dalam kandang.

Pengolahan untuk meningkatkan, mempertahankan kualitas misalnya jagung menjadi silase. Perlakuan kimiawi untuk pakan amoniase, contoh enzim hemiselulo yang memproduksi mikroba. Probiotik berfungsi menambah mikroba dalam pencernaan dan mendapat populasi mikroba sehingga pencernaan atau kecernaannya lebih bagus, zat aktif dalam probiotik berfungsi untuk proses pencernaan. Silase adalah pengawetan hijauan, hijauannya disini adalah rumput atau limbah pertanian. Pengolahan hijauan dalam bentuk silase untuk pengawetan pakan. Silase tidak mungkin akan diadopsi ketika hijauan segar untuk sapi tidak cukup. Hijauan yang berlebih ketika tidak dimanfaatkan, kemungkinan untuk dikonsumsi oleh ternak dalam kondisi rusak. Adapun cara membuat silase yakni hijauannya dipotong, kelompok bahan penguat/konsentrat berupa dedak 
padi/bekatul, onggok (ampas tapioca), ampas sagu, ampas tahu dan lain-lain. Selanjutnya dilakukan pencampuran dengan kelompok bahan penguat tersebut dan ditambahkan urea atau mineral, kemudian terakhir dibungkus anaerob selama 21 hari. Disimpan diatas 21 hari tidak menjadi masalah. Nanti kalau mau dipakai baru dibuka bungkusnya dianginkan sebentar baru diberikan pada ternak.

Aditif silase berfungsi sebagai Inhibitor atau penghambat, stimulant atau mendukung sumber nutrient makanan. Keberhasilan silase bukan karena pemberian dedak atau molasses tetapi harus ada kandungan diposanya. Dalam proses fermentasi mengaitkan asam laktat. Sehingga produksi PH menjadi rendah. Mikroba perusak yang bisa hidup dalam posisi ph rendah atau ph asam, sehingga ini silase pada umur 21 hari penyimpanan tidak boleh dibuka kalau tidak mau digunakan. Karena suasana asam berjalan terus menerus. Bakteri Asam Laktat memang sudah ada dalam mikroba, yang menentukan keberhasilan silase adalah kandungan nutrisi hijauan apakah tinggi atau rendah. Kedua, berapa besar bakteri asam laktat yang ada dihijauan. Mikroba perusak yang bisa berproduksi yaitu ph 4 (ph asam).

Keberhasilan silase yakni hari pertama hingga hari ke 21, dan yang harus diperhatikan adalah kedap udara karena bakteri tumbuh pada kondisi anaerob. Paling penting adalah setelah dan sebelum dicacah hijauan dilayukan, sehingga kadar air dalam hijauan mencapai $60 \%$. Aplikasi silase sangat menarik dimana petani melakukan integrasi tanaman jagung.

Pada dasarnya petani ternak di pedesaan selalu menginginkan ternakternaknya sehat dan terhindar dari berbagai penyakit yang berbahaya dan menular. Pada kondisi tertentu penyakit bisa berakibat fatal yang dapat menyebabkan kematian ternak, sehingga berpotensi menyebakan kerugian pada peternak. Beberapa di antara penyakit ternak kambing dan domba yang sering melanda masyarakat petani ternak adalah: Orf (bintumen), Kudis, Myasis, dan keracunan Pakan. Diantara rumput-rumputan atau daun-daunan ada yang mengandung racun dan dapat membahayakan ternak seperti daun jarak atau daun jawer kotok. Tandatanda klinis ternak yang keracunan adalah mati mendadak dengan ciri mulut berbusa, kejang-kejang, terjadi perdarahan (kotoran berdarah). Jika terjadi 
keracunan usaha pengobatan jarang berhasil. Pencegahan: Jangan memberikan makanan/hijauan yang beracun atau jangan mengembalakan ternak di daerah yang banyak tumbuhan beracun. Pengobatan Pada keracunan dini (baru), dapat dilakukan pemberian arang aktif (tablet Norit) atau diminumkan air kelapa muda.

\section{METODE}

Khalayak sasaran kegiatan penyuluhan cara beternak kambing dan domba adalah warga masyarakat yang terdampak pembangunan proyek PLTU Sumur Adem II Kabupaten Indramayu. Kegiatan dilaksanakan bertempat di Ruang Aula Balai Desa Patrol Baru dan Mekar Sari Kecamatan Patrol dengan jumlah sasaran yaitu 40 orang. Adapun yang menjadi instruktur dan narasumber dalam kegiatan ini adalah dosen-dosen Program Studi Agroteknologi dan Program Studi Agribisnis Fakultas Pertanian Universitas Wiralodra yang telah berpengalaman dalam mermelihara ternak kambing dan domba.

Pelaksanaan kegiatan pengabdian kepada masyarakat ini dilakukan dengan beberapa cara dengan tujuan agar proses penyampaian materi dapat berjalan dengan lancar maka pendampingan dilakukan dengan pendekatan individual dan klasikal. Pendekatan klasikal dilakukan pada saat pemberian teori tentang bagaimana merintis usaha ternak kambing dan domba. Pendekatan individual dilakukan pada saat latihan pemeliharaan ternak dan penyusunan serta pengolahan pakan ternak. Adapun metode yang digunakan adalah Ceramah Bervariasi, Demonstrasi, dan Latihan. Metode ini dilakukan untuk meningkatkan ketrampilan sasaran dalam penyusunan ransum dan pengolahan hijauan makanan ternak.

Adapun langkah-langkah kegiatan yang dilakukan pada kegiatan penyuluhan ini adalah sebagai berikut: 1) Ceramah tentang prospek beternak kambing dan domba. 2) Ceramah tentang penyusunan ransum ternak. 3) Ceramah tentang pengolahan hijauan makanan ternak. 4) Demonstrasi tentang langkahlangkah penyusunan ransum ternak dan pengolahan hijauan makanan ternak, 5). Latihan penyusunan ransum dan pengolahan hijauan makanan ternak. 6) Evaluasi hasil penyusunan ransum dan pengolahan hijauan makanan ternak 
Berdasarkan evaluasi pelaksanaan dan hasil kegiatan dapat diidentifikasi faktor pendukung dan penghambat dalam melaksanakan program pengabdian kepada masyarakat ini. Secara garis besar faktor pendukung dan penghambat tersebut adalah sebagai berikut:

\section{Faktor Pendukung}

a. Tersedia tenaga ahli yang memadai dalam pelatihan usaha ternak kambing dan domba dari Fakultas Pertanian Universitas Wiralodra

b. Antusiasme warga masyarakat yang cukup tinggi terhadap pelatihan penyusunan ransum dan pengolahan hijauan makanan ternak, karena banyak warga yang belum menguasai pembuatan hijauan makanan ternak olahan

c. Dukungan kepala desa dan jajarannya yang yang menyambut baik pelaksanaan kegiatan pelatihan dan membantu tim pengabdi mengorganisasikan waktu dan tempat pelaksanaan kegiatan.

d. Ketersediaan dana pendukung dari PLN wilayah pembangunan Jawa bagian Tengah dan Fakultas guna penyelenggaraan kegiatan pengabdian kepada masyarakat ini.

\section{Faktor Penghambat}

a. Warga peserta pelatihan masih banyak yang belum memiliki pengetahuan awal tentang cara beternak kambing dan domba, pemilihan bibit yang baik, penyusunan ransum dan pengolahan hijauan makanan ternak.

b. Keterbatasan waktu untuk pelaksanaan penyuluhan sehingga beberapa materi tidak dapat disampaikan secara detil.

c. Daya tangkap para peserta yang bervariasi, ada yang cepat namun juga ada yang lambat sehingga waktu yang digunakan kurang maksimal.

\section{PEMBAHASAN}

Kegiatan pengabdian kepada masyarakat yang dilaksanakan dengan acara tatap muka dan praktek beternak kambing berjalan dengan baik dan lancar. Pertemuan tatap muka dengan metode ceramah dan demonstrasi, dilanjutkan latihan/praktek untuk membuat formula ransum dan pengolahan hijauan makanan ternak. Kegiatan ini dilaksanakan masing-masing selama satu hari di dua tempat yang berbeda, yaitu pada hari Selasa tanggal 17 April 2018 dari pukul $08.00-15.00$ 
WIB di Desa Patro Baru dan pada hari Senin tanggal 14 Mei 2018 dari pukul 07.30 - 15.00 di Desa Mekarsari Kecamatan Patrol Kabupaten Indramayu. Peserta masing-masing kegiatan berjumlah 40 orang warga masyarakat Desa Patrol Baru dan Desa Mekarsari, dan berlokasi di Aula Balai Desa Patrol Baru dan Mekarsari. Pelaksanan kegiatan pengabdian kepada masyarakat ini ini dilakukan oleh 2 (dua) orang tim pengabdi dengan pokok bahasan yang disampaikan mengenai: 1) Prospek usaha ternak kambing dan domba. 2) Pemilihan Bibit Kambing dan Domba. 3) Penyusunan Formula Ransum. 4) Pengolahan Hijauan Makanan Ternak. 5) Latihan penyusunan formula ransum dan pengolahan hijauan makanan ternak. 6) Evaluasi formula ransum dan hasil pengolahan hijauan makanan ternak

Keterbatasan waktu pertemuan mengakibatkan tidak semua materi dapat disampaikan dengan detil. Kegiatan yang diawali dengan ceramah dan demonstrasi ini kemudian dilanjutkan latihan. Dari kegiatan latihan tampak bahwa warga masyarakat memang belum menguasai cara penyusunan formula ransum dan pengolahan hijauan makanan ternak dengan baik. Acara kemudian dilanjutkan sesi tanya jawab. Program pengabdian kepada masyarakat berupa penyuluhan beternak kambing dan domba bagi masyarakat yang terdampak proyek pembangunan PLTU PLN Sumur Adem II yang sudah dilaksanakan, ini diharapkan dapat menambah pengetahuan, keterampilan dan lebih percaya diri dalam menjalankan usaha ternaknya. Warga akan lebih semangat dan termotivasi untuk mengembangkan diri. Hasil pelatihan ini akan bermanfaat bagi masyarakat, karena menambah pendapatan keluarga. Disamping itu dengan adanya penyuluhan ini akan menambah pengetahuan dan keterampilan warga dalam beternak kambing dan domba dengan baik, sehingga akan mendukung dalam peningkatan kesejahteraan warga.

\section{SIMPULAN DAN SARAN}

\section{Simpulan}

Program pengabdian kepada masyarakat dapat diselenggarakan dengan baik dan berjalan dengan lancar sesuai dengan rencana kegiatan yang telah disusun meskipun belum semua warga masyarakat di tempat pelaksanaan kegiatan belum menguasai dengan baik materi yang disampaikan. Kegiatan ini mendapat sambutan sangat baik terbukti dengan keaktifan peserta mengikuti penyuluhan dengan tidak 
meninggalkan tempat sebelum waktu penyuluhan berakhir. Manfaat yang diharapkan dari kegiatan pengabdian kepada masyarakat ini adalah:

1. Memberikan pengetahuan dan keterampilan kepada warga masyarakat dalam beternak kambing dan domba yang baik sehingga dapat membantu pelaksanaan pemeliharaan ternak kambing dan domba yang akan diberikan PLN sebagai salah satu alternatif pengganti usaha tani yang dilakukan oleh warga.

2. Sebagai forum untuk bertukar pikiran antara warga masyarakat dengan perguruan tinggi dalam hal persiapan-persiapan bagi warga masyarakat yang akan menerima bantuan ternak kambing dan domba dari PLN.

\section{Saran}

Berdasarkan evaluasi yang telah dilakukan dapat diajukan beberapa saran sebagai berikut:

1. Waktu pelaksanaan kegiatan pengabdian kepada masyarakat perlu ditambah agar tujuan kegiatan dapat tercapai sepenuhnya, tetapi dengan konsekuensi penambahan biaya pelaksanaan. Oleh karena itu biaya PkM sebaiknya tidak sama antara beberapa tim pengusul proposal, mengingat khalayak sasaran yang berbeda pula.

2. Adanya kegiatan lanjutan yang berupa pelatihan sejenis selalu diselenggarakan secara periodik sehinga dapat meningkatkan kemampuan warga $\mathrm{d} \varepsilon^{*}$ melakukan usaha ternaknya..

\section{DAFTAR PUSTAKA}

AIID, R.M.A. 1992. Studi Kasus Beberapa Wabah Penyakit Orf(dakangan) pada kambing clan domba. Prosiding Agro-Industri Peternakan di Pedesaan. 10-11 Agustus 1992 Ciawi Bogor, Balai Penelitian Temak Bogor Indonasia.

Balai Informasi Pertanian Jawa Barat (BIP). 1995. Pengembangan Domba Garut Proyek Kerja Sama antara BIP Jabar dengan Pusat Perpustakaan Pertanian dan Komunikasi Pertanian Bogor.

Balai Penelitian Ternak. 1989. Kumpulan Pragaan Cara Beternak Domba dan Kambing Dalam Rangka Penelitian Pedesaan.(Balitnak clan Small Ruminant 
Colaborative Recearh Suport Programme. Balai Penelitian Ternak Ciawi Bogor.

Blakely, J. dan D. H. Bade. 1994. Ilmu Peternakan Cetakan ke -4. Gadjah Mada University Press, Yogyakarta. ( Diterjemahkan oleh B.Srigandono).

Chuzaemi, S dan Hartutik. 1988. Ilmu Makanan Ternak Khusus (Ruminansia). Universitas Brawijaya. Malang

Devendra, C., 2002. Crop-animal systems in Asia: future perspectives. Agric. Syst. 71, 179-186. Devendra, C., 2000. Challenges for research and development of goats. In: Proceedings International Conferences on Goats. France, 19-21 May 2000.

Devendra, C. and McLeroy, 1982. Goat and Sheep Production in the Tropics. Intermediate Tropical Agricultural Series, Longman Group Limited, Essex, UK.

Direktorat Jendral Peternakan dan Kesehatan Hewan. 2015. Buku Statistik Peternakan dan Kesehatan Hewan. Direktorat Jendral Peternakan dan Kesehatan Hewan. Kementrian Pertanian Republik Indonesia. Jakarta.

FAO, 1999. Poverty Alleviation and Food Security in Asia: Role of Livestock. RAP Publication 1999/4. Food and Agriculture Organization of the United Nations. Bangkok 10200, Thailand.

Hartadi, H., S. Reksohadiprodjo dan A. D. Tillman. 1986. Tabel Komposisi Pakan untuk Indonesia Cetakan ke -2. Gadjah Mada University Press, Yogyakarta.

Mulyono dan Sarwono. 2008. Spesifikasi Kambing Peranakan Ettawah dalam Pemeliharaan di Lingkungan yang Berbeda. Program Penyuluh Peternakan. Dinas Peternakan Jawa Timur. Surabaya.

Murtidjo, S. 1993. Memelihara Kambing sebagai Ternak Potong dan Perah. Penerbit Kanisius. Yokyakarta

National Research Council. 1981. Nutrient Requirements Of Sheep And Goats. www.aces.edu.

Santosa, U. 2006. Tatalaksana Pemeliharaan Ternak Ruminansia. Penebar Swadaya. Jakarta.

Setiawan, T. dan Arsa, T. 2005. Beternak Kambing Perah Peranakan Etawa. Penebar Swadaya, Jakarta.

Siregar, S. 1994. Ransum Ternak Ruminansia. Penebar Swadaya. Jakarta. 
Sodiq, A., 2005. Small ruminants: Implication and research strategies on rural poverty alleviation. J. Rural Dev. 1(7):1-7.

Sosroamidjojo. 1991. Ternak Potong dan Kerja. CV Yasaguna. Jakarta.

Sumoprastowo. 1980. Beternak Kambing yang Berhasil. Edisi Kedua. Penerbit Erlangga. Jakarta.

Utama, I. K. dan I. G. M. Budiarsana. 2009. Panduan Lengkap Beternak Kambing dan Domba. Penebar Swadaya, Jakarta.

Wilson, R.T., 1995. Livestock Production System. Macmillan Education, Ltd., Paris. 141pp. 